\title{
Effect of Previous Experience and Attitudes on Capstone Project Achieve- ment
}

\section{Prof. Byron G. Garry, South Dakota State University}

BYRON GARRY is an Associate Professor and Undergraduate Program Coordinator in the Department of Construction \& Operations Management in the College of Engineering at South Dakota State University and has taught the EET Project Management/Capstone course sequence since 2001. 


\title{
Effect of Previous Experience and Attitudes on Capstone Project Achievement
}

\begin{abstract}
This research was undertaken to see if there are any prior experiences or attitudes that students bring into the senior Capstone course that correlate with group Capstone project success. A variety of assessment techniques were used to obtain both quantitative measurements and qualitative indicators in an attempt to find common factors students have coming in to the course sequence that affect how well the projects succeed. There were several self-assessments by the students themselves, including pre-course survey of satisfaction with their achievement of and the importance to their career of all ABET-ETAC Criterion 3 Student Outcomes, a pre-course student biography including GPA, previous education, course and work experience, peer evaluations of team project work, and a pre-course self-assessment essay of how past course and work experience have prepared the student for the capstone project.

In addition, there were objective assessments of capstone project success done by the course instructor and project technical advisors. The measurements of Capstone project success were done as a part of demonstrating achievement of ABET-ETAC Student Outcomes, and they included assessment of initial hardware and/or software prototype at two months into the project, a Design Review of projects approximately half-way through the two-semester project, and the course instructor and project technical advisor assessment of project success, final reports and initial and final presentations.
\end{abstract}

This research involved a small study from a single program at one University, and may not be applicable in a wider setting. Quantitative and qualitative analysis of the data found, in general:

- student groups who, on average, are satisfied with their preparation in the area of the soft skills like teamwork, commitment to quality, and project management may tend to do better on their projects

- student groups that feel satisfied, on average, with their preparation in designing components, ability to identify problems, and ability to analyze and design systems may be less likely to do well in their projects.

- student groups with high GPAs, on average, do well on their projects

- student groups with more industry work experience, on average, tend to do better in the project's soft skills, as well as the ability overall to complete their projects successfully

- peer evaluations of group team work provided no data that related to project success

- the number of hours worked on the job tended to not have an effect on project success

Introduction

The 2012-13 ABET-ETAC Criterion 5 Curriculum section states that "Baccalaureate degree programs must provide a capstone or integrating experience that develops student competencies in applying both technical and non-technical skills in solving problems."1. A short search of ASEE Conference papers variously defines the goal of the Capstone experience is "to integrate the engineering and management disciplines into a single comprehensive educational experience" 2 "to provide a bridge for the students to cross between the academic world on one 
side and the technical professional world on the other", , to "provide an extensive platform to practice engineering design and to facilitate the integration of what students have learned throughout their curriculum" " "to better prepare graduates for engineering practice", and "to demonstrate their abilities to potential employers." All of these statements are appropriate and important. Using the measured outcomes of a Capstone course to assess how well students are prepared for engineering practice makes up an important and growing task for engineering and engineering technology programs.

In the B.S. Electronics Engineering Technology program, the EET 470/471 Project Management/ Capstone sequence takes place over two semesters. The Capstone course instructor is in charge of teaching project management tools and techniques during the first semester, and also acting as an overall Project Director, organizing project teams and assessing the groups' work against the standards that projects are expected to meet. In the first semester project teams define and begin their technical projects and in the second semester they do the majority of work and complete the projects. The position of technical advisor for each of the project groups is split among the EET faculty, based on the faculty member's area of expertise.

The EET program has defined, with the approval of alumni and its industrial advisory board, sixteen Student Outcomes that students should achieve by graduation, labeled a) - p). These begin with the ABET Criterion 3 Student Outcomes a) - k), and then add the Electrical / Electronic(s) Engineering Technology program specific requirements, and some university required student outcomes, which are labeled 1) - p).

There are seven, of the sixteen total Student Outcomes, that are assessed by the Capstone course instructor and project technical advisors, based on the Capstone project work, both during the project and at the end. They are, EET graduates have:

d) an ability to design systems, components, or processes for broadly-defined engineering technology problems appropriate to program educational objectives

e) an ability to function effectively as a member or leader on a technical team

f) an ability to identify, analyze, and solve broadly-defined engineering technology problems

k) a commitment to quality, timeliness, and continuous improvement

n) an ability to apply project management techniques

o) an ability to use appropriate engineering tools in the building, testing, operation, and maintenance of electronic systems

p) an ability to analyze, design, and implement electronic systems

Theory

The research question pursued in this paper is: Are there any prior experiences or attitudes that students bring in to the senior Capstone course that correlate with group Capstone project success? A variety of assessment techniques were used to obtain both quantitative measurements and qualitative indicators in an attempt to find common factors students have coming into the course sequence that may affect how well the Capstone projects succeed. Using both quantitative and qualitative data is an important trend in engineering education research. Borrego, et al. ${ }^{7}$, state that no particular method (quantitative, qualitative, or mixed) of education 
analysis is privileged over any other. Rather, the choice of method must be driven by the research questions. They say that quantitative methods are a good fit for deductive approaches, in which a hypothesis is tested using the appropriate statistical analysis. In particular, for data that is continuous, that is, using a scale, a Pearson's Correlation is an appropriate form of analysis $^{7}$. This is the form of quantitative analysis we used in this study.

Qualitative research is "characterized by the collection and analysis of textual data (surveys, interviews, focus groups, conversational analysis, observation, ethnographies)." ${ }^{8}$ While numbers can be used to summarize qualitative data, answering questions using qualitative data generally requires rich, contextual descriptions of the data, what is often called "thick" description". Ragin, et al. ${ }^{9}$ describe that qualitative research seeks detailed knowledge of specific cases, often with the goal of finding out "how" things happen. Kelly ${ }^{10}$ says that qualitative research is often exploratory; it is useful when it is necessary to investigate why something has happened or not happened, or to find out how well or otherwise something is performed, when quantitative data does not offer a complete picture. It is particularly suited to examining what people think, know, conceive or perceive. Qualitative studies are intended to inform readers about things they did not know or things they wanted to hear more evidence about or maybe had not even thought about.

Pomales-Garcia and $\mathrm{Liu}^{11}$ say an important part of a student's mindset is the development of knowledge, skills, and attitudes, which influence the student's goals. In their study of undergraduate student's attitudes toward excellence in engineering education, they used content analysis to analyze the data they gathered from student interviews. Content analysis is a research technique for analyzing text data and making replicable and valid inferences from data to their context $^{12}$. In this paper, we analyzed a pre-Capstone project essay for key descriptive terms or phrases that described the students' attitudes, and attempted to see if there were any that correlated with Capstone project success, as assessed by the course instructor.

One consideration to be careful with is that the course instructor's evaluation of project work, and the student's perception of their work, will not always be the same. Colwell ${ }^{13}$ reports that instructor's evaluations do not necessarily have a high correlation with how much students have learned, or perceive that they have learned. We do not claim that the results of this analysis prove in any manner a strong connection between the two perceptions, but there are interesting points raised by the results. A second consideration is, as Davis ${ }^{14}$ states, that while self-reported data alone is insufficient to demonstrate achievement of outcomes, surveys do provide useful snapshots of student perceptions that can be further investigated and supported by additional assessments. In this analysis we were using both self-reported and objective assessments.

The instructor's quantitative assessment of the student project work was done using rubrics. Each of the rubrics was developed starting with the results of educational research and have been modified over the years by the course instructor. There was a detailed rubric for each of the seven Student Outcomes assessed. Most of these rubrics were previously reported ${ }^{15}$. Mertler ${ }^{16}$ says that rubrics are rating scales - as opposed to checklists - that are used with performance assessments. They can be considered as scoring guides, consisting of specific pre-established performance criteria, and be used in evaluating student work. Rubrics are typically the specific form of scoring instrument used when evaluating student performances or products resulting from a performance task. Moskal ${ }^{17}$ describes that scoring rubrics are descriptive scoring used to 
guide the analysis of the products or processes of students' efforts. Scoring rubrics have also been used to evaluate group activities. Moskal ${ }^{17}$ also reports that the assignment of numerical weights to sub-skills within a process is an evaluation technique that may be used to determine the extent to which given criteria has been met. Scoring rubrics respond to this concern by providing descriptions at each level as to what is expected. Furtner ${ }^{6}$ describes a set of rubrics for grading senior design proposals. A practical goal of such a grading rubric can be to keep track of the points assigned to each of the individual sections of the proposal, which are used as assessment criteria for ABET Student Outcomes.

Platt-Mills and Bailey ${ }^{18}$ proposed a framework that identifies sources of variation in a student's capstone experience that are endogenous to the course (e.g., project type, team size) and exogenous to it (e.g., students' prior knowledge, students' demographics). Dutson, et al. ${ }^{19}$, in their review of capstone literature found that common measurement methods for factors could include surveys, official student records, or interviews. The data could be quantitative, qualitative, or a mix of both. This research follows a portion of Platt-Mills and Bailey's work, in that it was looking mostly at the exogenous factors that may affect student project success, such as prior work experience or attitudes.

\section{Method}

The data was gathered over two years from the Project Management/Capstone course sequence. There were a total of 26 students, divided into 7 project groups, ranging in size from two to five students per group. Students were allowed to pick their own groups, based on their interests and the project hardware and software requirements. For example, any project requiring extensive microcontroller software writing required team members who had taken electives in software, more than the one required software course in the EET curriculum. All the projects were completed, some with great success and others with not-so-great success.

Gathering personal data from students is a protected endeavor, and the research project was reviewed and approved by the university's Office of Research / Human Subjects Committee, \#IRB-1112021-EXM. The research's data gathering process is summarized in Figure 1.

\begin{tabular}{|l|l|l|l|l|}
\hline Instrument & Assessment by & $\begin{array}{l}\text { Pre- } \\
\text { course }\end{array}$ & $\begin{array}{l}\text { Mid- } \\
\text { course }\end{array}$ & $\begin{array}{l}\text { Post- } \\
\text { course }\end{array}$ \\
\hline 1. Student biography (work experiences) & Student & Sept & & April \\
\hline $\begin{array}{l}\text { 2. ABET Student Outcomes self-rating and } \\
\text { perceived importance to career }\end{array}$ & Student & Sept & & \\
\hline 3. Self-assessment essay & Student & Sept & & April \\
\hline 4. Peer assessment of team functioning & Student & & Dec & April \\
\hline $\begin{array}{l}\text { 5. Assessment of project, including Design } \\
\text { Review }\end{array}$ & $\begin{array}{l}\text { Technical Advisor } \\
\text { \& Course Instructor }\end{array}$ & & $\begin{array}{l}\text { Dec } \\
\text { \& Feb }\end{array}$ & April \\
\hline
\end{tabular}

Figure 1. Research project schedule

What follows are the instruments used for each evaluation, and a description of the numerical scale derived and used in the quantitative analysis. The first is Instrument \#1, Student Biography, seen in Figure 2. 


\begin{tabular}{|l|l|}
\hline $\begin{array}{l}\text { Name Current EET classes Current GPA } \\
\text { Previous school before pursuing the EET degree Transfer from other major }\end{array}$ \\
$\begin{array}{l}\text { Are you working at a part-time job now during the school year? Y or N, _ hrs/week } \\
\text { Briefly describe the job you have currently }\end{array}$ \\
\hline $\begin{array}{l}\text { Plans for school beyond BS degree } \\
\text { Past jobs where you used your technical degree skills/knowledge: } \\
\text { Company/location } \\
\text { Briefly describe your job duties _ - repeat as necessary }\end{array}$ \\
\hline
\end{tabular}

Figure 2. Instrument \#1 - Student Biography

The information gathered in this instrument is in words, but numbering scales were assigned, in order to be able to do a quantitative analysis. The student's GPA was recorded as a two-digit number, with the data ranging from 2.6 to 4.0, on a 4.0 scale. All students in the course had extensive work histories, but some had no work experience in the electronics industry. In order to do numerical correlations, the following scale was developed, after examining the information compiled. For past work experience, a scale of $1-5$ was chosen, determined by their description, where:

No experience in electronics, other than classwork $=1$

Worked in an electronics manufacturing company for at least 1 year as technician or in design support $=3$

Worked as an electronics technician (with an AAS ET degree, and now finishing their BS EET degree) for over 5 years $=5$

Almost all students were working as the course was ongoing. For the extent of work, a scale of 1 -5 was chosen, determined by their description, where:

Not working at all $=1$

Up to $10 \mathrm{hrs} / \mathrm{week}=2$

$10 \mathrm{hrs} /$ week, up to $19=3$

$20 \mathrm{hrs} /$ week or more, but still part-time $=4$

Full-time work (part-time school) $=5$

In Instrument \#2, we had the students rate themselves on all Student Outcomes a) - p). We did this before and after the course. We used this statement, "Based on your coursework to this point, how confident or satisfied are you in your ability to", for all sixteen Student Outcomes, using a scale of:

Very Confident or Satisfied $=5$

Confident or Satisfied $=4$

Neutral $=3$

Not Confident or Satisfied $=2$

Very Unconfident or Unsatisfied $=1$

We also had them answer, for all Student Outcomes a) - p), "How important do you think this skill will be in your professional career", using a scale of:

Very Important $=5$

Somewhat important $=4$

Average importance $=3$

Below average importance $=2$

Not at all important $=1$ 
Instrument \#3, a self-assessment essay used the following wording (from Davis ${ }^{14}$ ). Qualitative analysis was done on the essays, as described later.

Pre-course essay: Please write a short essay (a minimum of 2 paragraphs long, with each paragraph with a minimum of 6 sentences) describing how your previous work experience and program coursework has prepared you to undertake your Senior Capstone project.

Instrument \#4 was a peer evaluation, done at the middle and at the end of the projects by the students in the project teams, as seen in Figure 3. No numbers were used when the students filled out the evaluation. They were added later, by the course instructor, as shown, in order to do statistical analysis.

\begin{tabular}{|c|c|c|}
\hline \multicolumn{3}{|c|}{$\begin{array}{l}\text { Please write the names of all your team members, INCLUDING YOURSELF, and rate the } \\
\text { degree to which each member fulfilled his/her responsibilities in completing their assigned } \\
\text { tasks. The possible ratings are as follows: }\end{array}$} \\
\hline Excellent & $\begin{array}{l}\text { Consistently went above and beyond - helped teammates, carried more } \\
\text { than his/her fair share of the load. }\end{array}$ & 10 \\
\hline Very Good & $\begin{array}{l}\text { Consistently did what he/she was supposed to do, very well prepared } \\
\text { and cooperative }\end{array}$ & 9 \\
\hline Satisfactory & $\begin{array}{l}\text { Usually did what he/she was supposed to do, acceptably prepared and } \\
\text { cooperative }\end{array}$ & 8 \\
\hline Ordinary & $\begin{array}{l}\text { Often did what he/she was supposed to do, minimally prepared and } \\
\text { cooperative }\end{array}$ & 7 \\
\hline Marginal & Sometimes failed to show up or complete assignments, rarely prepared & 6 \\
\hline Unsatisfactory & Consistently failed to show up or complete assignments, unprepared & 3 \\
\hline Superficial & Practically no participation & 2 \\
\hline No show & No participation at all & 0 \\
\hline
\end{tabular}

Figure 3. Peer evaluation form

Instrument \#5, evaluation of Student Outcomes, was done by the course instructor and technical advisor, using the following rubrics, seen in Figure 4, to assess project's progress on these items. When the assessment was made more than once over the course of the project, the results were averaged together. (Note: it was decided in the EET program years ago that all assessment of Student Outcomes would use a 10 point scale, to be able to more easily use percentages on tests and quizzes as assessment data. In reality, the assessment ratings actually use a 5 point scale. For this research paper, the 10 point scale was retained. An analysis changing the rating scale to a 5 point scale did not have an effect on the correlation values found in the analysis.)

\begin{tabular}{|l|l|l|l|l|l|}
\hline ABET Outcome & \multicolumn{1}{c|}{ Superior } & \multicolumn{1}{c|}{ Excellent } & \multicolumn{1}{c|}{ Good } & \multicolumn{1}{c|}{ Fair } & \multicolumn{1}{c|}{ Poor } \\
\cline { 2 - 6 } & \multicolumn{1}{|c|}{10} & \multicolumn{1}{c|}{9} & \multicolumn{1}{c|}{8} & \multicolumn{1}{c|}{$7-6$} & \multicolumn{1}{c|}{$5-0$} \\
\hline $\begin{array}{l}\text { d) ability to } \\
\text { design* systems, } \\
\text { components, or } \\
\text { processes }\end{array}$ & $\begin{array}{l}\text { Design process is } \\
\text { thorough, based in } \\
\text { theory, and executed } \\
\text { very well }\end{array}$ & $\begin{array}{l}\text { Mostly } \\
\text { thorough, based } \\
\text { partly in theory, } \\
\text { and executed } \\
\text { well }\end{array}$ & $\begin{array}{l}\text { Somewhat } \\
\text { thorough, } \\
\text { based } \\
\text { somewhat in } \\
\text { theory, and } \\
\text { executed good } \\
\text { Any redesign needed } \\
\text { in mid-project done } \\
\text { thoroughly }\end{array}$ & $\begin{array}{l}\text { little theory, } \\
\text { executed fair } \\
\text { needed in mid- } \\
\text { project done } \\
\text { well }\end{array}$ & $\begin{array}{l}\text { Redesign not } \\
\text { tone well } \\
\text { theory, no } \\
\text { executed } \\
\text { poorly }\end{array}$ \\
\hline
\end{tabular}




\begin{tabular}{|c|c|c|c|c|c|}
\hline e) teamwork & $\begin{array}{l}\text { Completes all } \\
\text { assigned tasks by } \\
\text { deadline without } \\
\text { prompting } \\
\text { Work accomplished } \\
\text { is thorough, } \\
\text { comprehensive, and } \\
\text { advances the project } \\
\text { Proactively helps } \\
\text { other team members } \\
\text { complete their } \\
\text { assigned tasks to a } \\
\text { similar level of } \\
\text { excellence }\end{array}$ & $\begin{array}{l}\text { Completes all } \\
\text { assigned tasks } \\
\text { by deadline } \\
\text { Work } \\
\text { accomplished is } \\
\text { thorough and } \\
\text { advances the } \\
\text { project } \\
\text { Works with } \\
\text { other team } \\
\text { members as } \\
\text { required. }\end{array}$ & $\begin{array}{l}\text { only with } \\
\text { prompting }\end{array}$ & $\begin{array}{l}\text { only on } \\
\text { some tasks }\end{array}$ & $\begin{array}{l}\text { little work } \\
\text { done }\end{array}$ \\
\hline $\begin{array}{l}\text { f) ability to } \\
\text { identify, analyze } \\
\text { and solve } \\
\text { problems }\end{array}$ & $\begin{array}{l}\text { Design process } \\
\text { completely detailed } \\
\text { All appropriate } \\
\text { supporting } \\
\text { documents present in } \\
\text { written report } \\
\text { Clear understanding } \\
\text { of design process } \\
\text { demonstrated }\end{array}$ & $\begin{array}{l}\text { Mostly detailed } \\
\text { Most }\end{array}$ & $\begin{array}{l}\text { Basically } \\
\text { detailed } \\
\text { Some }\end{array}$ & $\begin{array}{l}\begin{array}{l}\text { Sketchily } \\
\text { detailed }\end{array} \\
\text { Few }\end{array}$ & Not detailed \\
\hline $\begin{array}{l}\text { k) commitment to } \\
\text { quality, timeliness } \\
\text { and continuous } \\
\text { improvement }\end{array}$ & $\begin{array}{l}\text { Reasons with all } \\
\text { good/correct results } \\
\text { and/or interprets data } \\
\text { very well. } \\
\text { Develops exemplary } \\
\text { conclusions based on } \\
\text { results. }\end{array}$ & $\begin{array}{l}\text { mostly good / } \\
\text { correct results } \\
\text { and/or interprets } \\
\text { data well. } \\
\text { good } \\
\text { conclusions } \\
\text { based on results. }\end{array}$ & \begin{tabular}{|l} 
some good/ \\
correct results \\
and interprets \\
data somewhat \\
some good \\
conclusions \\
based on some
\end{tabular} & $\begin{array}{l}\text { minimal } \\
\text { good/correct } \\
\text { results and } \\
\text { interprets } \\
\text { some data } \\
\text { minimal } \\
\text { conclusions }\end{array}$ & $\begin{array}{l}\text { poor results } \\
\text { and/or } \\
\text { interprets } \\
\text { data poorly } \\
\text { poor } \\
\text { conclusions }\end{array}$ \\
\hline $\begin{array}{l}\text { n) apply project } \\
\text { management } \\
\text { techniques }\end{array}$ & $\begin{array}{l}\text { Project is planned } \\
\text { thoroughly and } \\
\text { completely, and } \\
\text { executed very closely } \\
\text { to plan }\end{array}$ & $\begin{array}{l}\text { Project is } \\
\text { planned } \\
\text { thoroughly, and } \\
\text { executed mostly } \\
\text { to plan } \\
\end{array}$ & \begin{tabular}{|l} 
Planned \\
thoroughly, \\
and executed \\
far from plan
\end{tabular} & $\begin{array}{l}\text { Planned } \\
\text { loosely, and } \\
\text { executed far } \\
\text { from plan }\end{array}$ & $\begin{array}{l}\text { Little plan, } \\
\text { and } \\
\text { execution } \\
\text { haphazard }\end{array}$ \\
\hline $\begin{array}{l}\text { o) ability to use } \\
\text { tools in building } \\
\text { and testing of } \\
\text { electronic sys. }\end{array}$ & $\begin{array}{l}\text { Hardware and } \\
\text { software tools used } \\
\text { very well }\end{array}$ & $\begin{array}{l}\text { Hardware and } \\
\text { software tools } \\
\text { used well }\end{array}$ & $\begin{array}{l}\text { Hardware and } \\
\text { software tools } \\
\text { used good }\end{array}$ & $\begin{array}{l}\text { Fair use of } \\
\text { tools }\end{array}$ & $\begin{array}{l}\text { Poor use of } \\
\text { tools }\end{array}$ \\
\hline $\begin{array}{l}\text { p) ability to } \\
\text { analyze, design* } \\
\text { and implement } \\
\text { electronic } \\
\text { systems }\end{array}$ & $\begin{array}{l}\text { Design process } \\
\text { completely detailed } \\
\text { All supporting } \\
\text { documents present in } \\
\text { written report } \\
\\
\text { Clear understanding } \\
\text { of design process } \\
\text { demonstrated }\end{array}$ & $\begin{array}{l}\text { Mostly detailed } \\
\text { Most }\end{array}$ & $\begin{array}{l}\begin{array}{l}\text { Basically } \\
\text { detailed }\end{array} \\
\text { Some }\end{array}$ & $\begin{array}{l}\begin{array}{l}\text { Sketchily } \\
\text { detailed }\end{array} \\
\text { Few }\end{array}$ & Not detailed \\
\hline
\end{tabular}

Figure 4. Student Outcome Capstone project assessment rubrics 
*Note in the table that both Student Outcomes d) and p) use the word "design" in their definition. From the rubrics, and in general use by the Capstone course instructor over the years, Student Outcome d) was evaluated for how well the project team designs individual parts of the project, such as a microcontroller sensor interface circuit or the software code written for that sensor. Student Outcome p) was evaluated looking at the final system as a whole, and if the project group had detailed documentation (and implied, clear understanding) of how their design process was carried out.

Quantitative analysis of data and results

The research question pursued in this paper is: Are there any prior experiences or attitudes that students bring into the senior Capstone course that correlate with group Capstone project success? With only 26 students involved in 7 project groups, there was not enough evidence, or rigor in the survey instruments, to make any claims of causation for any of the results found. Because it is impossible to tell what effect each student has on the Capstone project's success, we computed an average score for the group. But, there was a large enough sample size (26) to be able to do a Pearson's Correlation on data gathered and get statistically significant results. It may be not completely statistically valid to use a group average in place of the individual student self-assessments. Because of this, it was a given that any statistical relationships found do not show causation, and even if statistically significant results were found, only broad generalizations can be made that might not extend to other situations.

We chose to do 2-tailed tests, because the Pearson's correlation $r$ could be positive or negative, and we chose to test to a $\mathrm{p}<0.05$ level of significance. With data from 26 students, the degrees of freedom is $\mathrm{df}=25$. The various correlations of data were calculated using a null hypothesis of [H0: $r=0-$ there is no correlation between the two sets of data] versus the alternate hypothesis

[H1: $r \neq 0$ - there is a correlation between the two sets of data.]

Using SPSS software, calculations of Pearson's Correlation between sets of data was done, such as the group average self-rating of each Student Outcome, before project started, compared to the instructor rating of the same, using information from the projects. The following figures show all the results that were statistically significant, that is, with $\mathrm{p}<0.05$ value. Some were positive correlations and some were negative correlations.

Using Instrument \#2, we gathered the data about the seven Student Outcomes - d, e, f, k, n, o, and $\mathrm{p}$ - "How confident or satisfied are you in your ability to do these" and "How important do you think this skill will be in your professional career" from each student, and found a group average. These values ranged from 3.5 to 4.9 Using Instrument \#5, the assessment rubrics used by the course instructor and technical advisors, we assigned a score to each of the seven Student Outcomes - again d, e, f, k, n, o, and p - for each project group. The instructor ratings ranged in value from 5 to 10. This gave us a paired set of data that we could use to do a hypothesis test, and calculate a Pearson's Correlation value, r. Figure 5 shows that all seven of the Student Outcomes measured were found to be statistically significant, some with positive and some with negative correlations. 


\begin{tabular}{|l|c|}
\hline $\begin{array}{l}\text { Group Self-rating (pre-project) vs Instructor rating (post-project) } \\
\text { of Student Outcomes }\end{array}$ & $\begin{array}{c}\text { Correlations r, } \\
\text { with } \mathrm{p}<0.05\end{array}$ \\
\hline \multicolumn{1}{|c|}{ Positive correlations } \\
\hline e) teamwork & +0.720 \\
\hline k) commitment to quality, timeliness and continuous improvement & +0.587 \\
\hline n) apply project management techniques & +0.740 \\
\hline o) ability to use tools in building and testing of electronic systems & 0.632 \\
\hline \multicolumn{2}{|c|}{ Negative correlations } \\
\hline d) ability to design systems, components, or processes & -0.460 \\
\hline f) ability to identify, analyze and solve problems & -0.377 \\
\hline p) ability to analyze, design and implement electronic systems & -0.599 \\
\hline
\end{tabular}

Figure 5. Self-rating vs Instructor rating of Student Outcomes

This data suggests that, averaged across the members in the project group, those who felt they did well in e) teamwork, k) commitment to quality, n) project management, and o) ability to use tools were more likely to do well on the Capstone project. Conversely, averaged across the members in the project group, those that thought they did well in d) design, f) solve problems, and p) design and implement electronic systems did not do as well on the project.

Finding this set of correlations was the main idea behind doing this study, and these results have good and bad connotations. Again, with the caveat that this data does not show causation, we can make the generalization that students who are satisfied with their preparation from their degree coursework in the area of e) teamwork, $\mathrm{k}$ ) commitment to quality, n) project management, and o) ability to use tools tend to do better on their capstone project work. This generalization implies that the "soft skills" of teamwork and quality, as described by Shuman, et al. ${ }^{20}$, are important to success in a technical project. Those that feel satisfied with their preparation in d) design, f) ability to identify problems, and p) ability to analyze and design systems were less likely to do well in their Capstone project. A conjecture may be made that students who feel confident in their technical skills of design going into their Capstone may actually be over-confident and may not do the work needed to succeed.

There were other interesting results. Figure 6 shows the correlation of group average GPA to the instructor rating of all seven Student Outcomes measured. All were large positive correlations. This study was started with the hope that it would not turn out to only have a result of "high GPA = good projects", but this factor produced the highest positive correlations. It is probably selfevident that students who have worked hard to get good grades would continue to work hard and succeed in their Capstone project.

\begin{tabular}{|l|c|}
\hline $\begin{array}{l}\text { Group GPA (pre-project) vs Instructor rating (post-project) of } \\
\text { Student Outcomes }\end{array}$ & $\begin{array}{c}\text { Correlations } \mathrm{r}, \\
\text { with } \mathrm{p}<0.05\end{array}$ \\
\hline d) ability to design systems, components, or processes & +0.614 \\
\hline e) teamwork & +0.583 \\
\hline f) ability to identify, analyze and solve problems & +0.753 \\
\hline k) commitment to quality, timeliness and continuous improvement & +0.732 \\
\hline n) apply project management techniques & +0.455 \\
\hline o) ability to use tools in building and testing of electronic systems & +0.768 \\
\hline p) ability to analyze, design and implement electronic systems & +0.834 \\
\hline
\end{tabular}

Figure 6. Group GPA vs Instructor rating of Student Outcomes 
In Figure 7 we look at any correlations between the years of work experience students have and the instructor rating of project group work. There are positive correlations for e) teamwork, $\mathrm{k}$ ) commitment to quality, $n$ ) project management, and $p$ ) ability to design systems. Notice that three of the four significant correlations were on soft skills. Students who have worked in industry will have had more opportunities than those who haven't to practice these skills, and may become more proficient at them. There was also a correlation with the overall design of the system. This suggests that students with industry experience have experienced the need to do "whatever it takes" to complete a project successfully, and carried that into their Capstone project.

\begin{tabular}{|l|c|}
\hline $\begin{array}{l}\text { Group Years of experience (pre-project) vs Instructor rating (post- } \\
\text { project) of Student Outcomes }\end{array}$ & $\begin{array}{c}\text { Correlations r, } \\
\text { with } \mathrm{p}<0.05\end{array}$ \\
\hline e) teamwork & +0.583 \\
\hline k) commitment to quality, timeliness and continuous improvement & +0.375 \\
\hline n) apply project management techniques & +0.740 \\
\hline p) ability to analyze, design and implement electronic systems & +0.834 \\
\hline
\end{tabular}

Figure 7

Some of the analysis did not include any averaging for the project groups. The overall average, from Instrument \#2, of self-ratings and importance to career for all Student Outcomes, for only the seven Outcomes that are rated by the instructor in the Capstone project, are given in Figure 8.

\begin{tabular}{|c|c|c|}
\hline Student Outcome - all students individually & Self-rating & $\begin{array}{c}\text { Importance to } \\
\text { career }\end{array}$ \\
\hline d) ability to design systems, components, or processes & 3.7 & 4.0 \\
\hline e) teamwork & 4.7 & 4.7 \\
\hline f) ability to identify, analyze and solve problems & 3.9 & 4.3 \\
\hline k) commitment to quality, timeliness and continuous improvement & 4.5 & 4.7 \\
\hline n) apply project management techniques & 3.7 & 4.5 \\
\hline o) ability to use tools in building and testing of electronic systems & 4.2 & 4.4 \\
\hline p) ability to analyze, design and implement electronic systems & 3.8 & 4.4 \\
\hline
\end{tabular}

Figure 8. Student self-rating and importance in career

Overall, students see themselves as confident to very confident (values of 4.0 or above), in e) teamwork, k) commitment to quality, timeliness and continuous improvement, and o) ability to use tools in building and testing of electronic systems. They see themselves less than confident (values $<4.0$ ) in d) ability to design systems, components or processes, f) ability to identify, analyze and solve problems, n) apply project management techniques, and p) ability to analyze, design and implement electronic systems. The students as a whole see all seven of the Student Outcomes assessed as being important in their careers in the future, with only small variations in degree of importance. There are no further conclusions to be drawn from this part of the data.

A positive correlation was found with individual student's GPA and the number of years of experience working in the electronics filed, with $r=0.577, p<0.002$. This is an encouraging result, which implies that work experience is a valuable part of obtaining good grades toward a BSEET degree. 
The next question considered was how students rated themselves in the Student Outcomes before the project started was correlated their individual GPA. Figure 9 shows these results of his analysis. These numbers suggest that students who, individually, have a high GPA coming into the capstone Project, see themselves as good at e) teamwork, k) commitment to quality, and o) ability to use tools. Those students with high GPA tend to see themselves as not as well prepared in p) ability to implement systems. That suggests that these "good" students do not have self-confidence in that area.

\begin{tabular}{|l|c|}
\hline Individual Self-rating (pre-project) vs GPA (pre-project) & $\begin{array}{c}\text { Correlations r, } \\
\text { with } \mathrm{p}<0.05\end{array}$ \\
\hline \multicolumn{2}{|c|}{ Positive correlations } \\
\hline e) teamwork & +0.720 \\
\hline k) commitment to quality, timeliness and continuous improvement & +0.399 \\
\hline o) ability to use tools in building and testing of electronic systems & +0.506 \\
\hline Negative correlations & -0.395 \\
\hline p) ability to analyze, design and implement electronic systems
\end{tabular}

Figure 9. Individual Self-rating (pre-project) vs GPA (pre-project)

There were other factors measured where there were no statistically significant correlations found, or the correlations were close to zero. These were:

- peer evaluations of group work gathered from Instrument \#4, as compared to any of the Students Outcomes measured by the instructor

- any factors compared to Student Outcome "importance to career" data, and

- the amount of hours being worked as the Capstone project was being done, as compared to any of the Students Outcomes measured by the instructor

This last finding is a good result, to see that the number of hours of work on the job that a student was doing had no correlation to how well their Capstone project succeeded. This suggests that students who work hard at their jobs can concurrently work hard on their project. The result that peer evaluations also had no correlation to project success was not a surprise to the author. The sense that students tend to not evaluate each other harshly in their project group, at least officially in a survey, was assumed before, and with this "non-correlation" found, the sense was strengthened.

From Instrument \#1, student biography, we saw that of the 26 students in the project groups, only 5 could be considered traditional, that is, started in the EET program right out of high school. The largest grouping of students transferred from other majors, but has less than six total years of higher education, with 12 identified as such. There were 5 with military electronics training and experience prior to starting the program, and 4 with an AAS degree in Electronics Technology from one of the Technical Institutes in the state, who articulated into the BSEET program. The students with different educational backgrounds were distributed through all the project groups evenly, and there were no significant correlations found with any other factors.

Another type of quantitative, but purely descriptive, analysis is the use of a scatter plot (after Davis $^{14}$ ). Using the data collected from Instrument \#2, a scatter plot was made of the importance to their career versus self-rating of all sixteen Student Outcomes. Figure 10 shows this scatter plot. The average self-rating was 4.11 , and the average importance to career 4.25 . These are marked with the dashed lines in the graph. Notice that the Student Outcomes in the upper right 
quadrant - those that students consider that, relative to all the Student Outcomes, they can do well and are important to their future, are a, h, m, k, e. The lower left quadrant - those that students think they can't do as well and are not as important to their future, are $\mathrm{g}, \mathrm{d}, \mathrm{j}$.

Not all of these Student Outcomes are assessed for the project, but notice those that are. In the quantitative analysis above, Student Outcomes e) and k) were found to be positively correlated to instructor rating of the group in that area, and d) was found to be negatively correlated to the instructor rating of the group in that area. This implies that the areas that students, before they started on their Capstone project, thought they did well in, and were important to their future, were those areas they did well on for the project, in the course instructor's ratings. The area that they did not have as much confidence in their ability, and did not think would be important to their future, d), had a negative correlation, where the instructor rated them worse than they thought they would be.

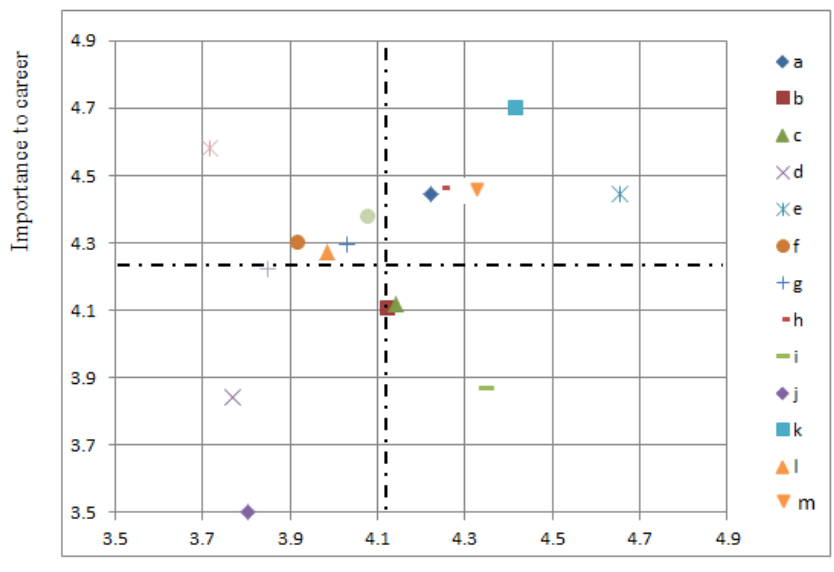

Self-rating

Figure 10. Scatter plot of "importance to career" versus self-rating of Student Outcomes

Qualitative analysis of data

A type of qualitative analysis called content analysis was done of the data from Instrument \#3, the student's pre-course essay. Berg ${ }^{21}$ says that content analysis can include both quantitative and qualitative analysis. We began with a quantitative analysis of the main terms and phrases mentioned in the essays. A coding scheme was started deductively before reading the essays, based on the author's expectations, and was further expanded inductively, after a thorough reading of the essays, to see what terms or phrases were present. Any term or phrase that was mentioned at least five times was included in the coding, for a total of 18 key terms or phrases. The terms were combined somewhat, with some combination when exact words were not used, such as Navy, Air Force, or National Guard electronics training were combined to be "military training", and writing about their work experience were assembled under the term "work in general"'.

Then the essays were analyzed again, with a notation made for each key term the student used in their essay. The key terms or phrases used, starting from those used most (26 times) to least (5 times) were: work in general, confidence, increasing responsibility in work assignment, $\mathrm{DC} / \mathrm{AC} /$ components courses, teamwork, communication skills, specific troubleshooting and test 
experience at work, Prototype course, hands-on/build experience, design experience, project management work experience, military training, customer service, Microcontrollers /

Programming courses, leadership, deadline/time management experience, and work experience concurrent to coursework.

This data was put into an Excel spreadsheet. A count was made of the total number of identified key terms or phrases used by members of the project groups, and an average number of terms used by group members, were computed. These ranged from a high of 9.4 key terms to a low of 4.3 key terms per student. We used these numbers to look at any possible correlations to the average GPA of the project group and the average of all seven Student Outcomes measured (range of 6.9 to 9.1), which were compiled from the quantitative data. Then a ranking was made of the seven project groups in all three categories: Student Outcome ratings, GPA, and average number of terms used in the essay. This was done to investigate, for example, if the groups that had the highest average number of key terms in the essay were also the highest rated groups in Student Outcomes ratings. This question came from the conjecture that students that were more self-aware of their course and work experience and have had more experience would do better overall on the Capstone project. The results of this analysis are seen in Figure 11.

\begin{tabular}{|c|c|c|c|}
\hline Group ID & $\begin{array}{c}\text { Ranking of } \\
\text { Student Outcomes } \\
\text { assessed }\end{array}$ & $\begin{array}{c}\text { Ranking of } \\
\text { Group GPA }\end{array}$ & $\begin{array}{c}\text { Ranking of average } \\
\text { number of key terms } \\
\text { used by group members }\end{array}$ \\
\hline A & 4 & 5 & 3 \\
\hline B & 7 & 7 & 2 \\
\hline C & 3 & 1 & 7 \\
\hline D & 5 & 4 & 5 \\
\hline E & 6 & 6 & 4 \\
\hline F & 1 & 2 & 1 \\
\hline G & 2 & 3 & 6 \\
\hline
\end{tabular}

Figure 11. Ranking of project teams in three factors

For example, project group $\mathrm{G}$ ranked $2^{\text {nd }}$ in Student Outcomes ratings, and $1^{\text {st }}$ in average number of terms used in the essay. But this analysis could not be extended to any type of relationship between the two categories; project group B ranked $7^{\text {th }}$ (last) in Students Outcomes ranking, but were $2^{\text {nd }}$ in average number of terms used in the essay. Comparing group GPA and average number of terms produced the same non-correlations: project group $\mathrm{C}$ had the highest ranking in group GPA, but used the $6^{\text {th }}$ ranked average number of terms in the essay, and project group B ranked $7^{\text {th }}$ in GPA, but ranked $2^{\text {nd }}$ in average number of terms used. So we conclude that the student self-assessment essay done before the Capstone project starts, measured by the number of key terms or phrases used, holds no correlation to project success as measured by the course instructor.

In addition, individual key terms, or groups of key terms (for example, combining the "soft skills" of teamwork, leadership, and communication) were analyzed, to see if the number of these specific key terms used had any relation with the rankings in Student Outcomes ratings. There were no relationships found from this analysis, either.

Analyzing what were the key terms and phrases for the entire group of students, there were two that came up in the essays that were surprising to the author. The term confident, or having 
confidence in the success of their Capstone project, was mentioned by 22 of the 26 students, even though the phrase used in the instrument is "prepared you to undertake your Senior Capstone project". This says that the students are confident about their abilities to do their Capstone project before they start their project, even when the subsequent project was not done well. Also surprising was the fact that the introductory electronics course, DC/AC Analysis, or basic component knowledge, was mentioned as a positive factor by 16 of 26 students. Since for many of the students, especially those that had military electronics training, it had been years since they had started their electronics course of study, they were confident going into their Capstone project because they had a good foundation in their field.

What does this mean about the qualitative analysis of the pre-course essay done for this study? For the variables investigated, there were no relationships found. It was still felt by the author that this was a worthwhile effort, and may lead to more analysis in the future. For example, is there any relationship in differences between how students wrote their pre- and post-course essays versus project group success? This was not investigated for this study.

\section{Limitations}

This research involved a small study from a single program at a University, and may not be applicable in a wider setting. With only 26 students involved in 7 project groups, there was not enough evidence, or rigor in the survey instruments, to make any claims of causation for any of the results found. Because it is impossible to tell what effect each student has on the Capstone project's success, we computed an average score for the group. It may be not completely statistically valid to use a group average in place of the individual student self-assessments. Because of this, it was a given that any statistical relationships found do not show causation, and even if statistically significant results were found, only broad generalizations can be made that might not extend to other situations.

\section{Conclusions}

Research was done to see if there were any prior experiences or attitudes that students bring into the senior Capstone course that correlate with group Capstone project success, using both quantitative and qualitative assessments. Both students' opinions gathered from surveys, indirect evidence, and instructor ratings of Capstone project success, direct evidence, were gathered. The data gathered was not a large enough sample size to make definite conclusions, but from the quantitative analysis, generalizations are suggested that:

- student groups who, on average, are satisfied with their preparation from their degree coursework in the area of the soft skills like teamwork, commitment to quality, and project management may tend to do better on their projects

- $\quad$ student groups that feel satisfied, on average, with their preparation in designing components, ability to identify problems, and ability to analyze and design systems may be less likely to do well in their projects. This is conjectured by the author to be a result of over-confidence in their technical skills going into the project, and the teams may not do the work needed to succeed.

- student groups with high GPAs, on average, do well on their projects 
- student groups with more industry work experience, on average, tend to do better in the course instructor's evaluation of their soft skills, like teamwork, commitment to quality, project management, as well as the overall ability to complete their projects successfully

- peer evaluations of group team work, as currently done, provided no data that related to project success

- the number of hours worked on the job tended to not have an effect on project success

The qualitative analysis found that analyzing the student self-assessment essay done before the Capstone project starts, measured by the number of key terms or phrases used, holds no correlation to project success as measured by the course instructor. Further investigation into more qualitative data may reveal more relationships in future research.

\section{Bibliography}

1. ABET. 2012-13 Criteria for Accrediting Engineering Technology Programs. Accreditation Board for Engineering and Technology, Engineering Technology Accreditation Commission. Baltimore, MD. Retrieved Nov 1, 2012 from www.abet.org

2. Nguyen, H., McIntyre, C., \& Diab, M. 2005. Measuring Learning Performance of an Engineering Capstone Course with respect to the ABET Engineering Criteria. Proceedings of the 2005 ASEE North Midwest Conference, Brookings, SD

3. Lillevik, S.L. 2004. Capstone Design through Cooperative Learning. Proceedings of the 2004 ASEE Annual Conference \& Exposition, Salt Lake City, UT

4. Potter, L. \& Min, J. 2005. ABET Outcome Assessment in an Industrial Engineering Capstone Design Course. Proceedings of the 2005 ASEE North Midwest Conference. Brookings, SD

5. Akili, W. 2008. Teaching Capstone Design for Students in Civil Engineering: A Partnership between academics and Practitioners. Proceedings of the 2008 ASEE North Midwest Conference, Platteville, WI

6. Furtner, R.G. 2005. From Subjective to Objective: Using Detailed Rubrics for Grading Senior Design Proposals. Proceedings of the 2005 ASEE North Midwest Conference, Brookings, SD

7. Borrego, M., E.P. Douglas, and C.T. Amelink. 2009. Quantitative, Qualitative, and Mixed Research Methods in Engineering Education. Journal of Engineering Education 98(1):53-66.

8. Olds, B.M., B.M. Moskal and R.L. Miller. 2005. Assessment in Engineering Education: Evolution, Approaches and Future Collaborations. Journal of Engineering Education 94(1):13-25.

9. Ragin, C.C., J. Nagel and P. White. 2003. Workshop on Scientific Foundations of Qualitative Research Report. National Science Foundation. Retrieved Nov 1, 2012 from http://www.nsf.gov/pubs/2004/nsf04219/nsf04219.pdf

10. Kelly, K. and Bowe, B. 2011. Qualitative Research Methods in Engineering. Proceedings of the 2011 ASEE Annual Conference \& Exposition, Vancouver, BC

11. Pomales-Garcia, C. and Liu, L. 2007. Excellence in Engineering Education: Views of Undergraduate Engineering Students. Journal of Engineering Education 96(5):253-256 
12. Krippendorff, K. 1980. Content Analysis: An Introduction to its Methodology, Beverly Hills, CA, Sage Publications v.5

13. Colwell, J.L. 2004. Tools for Using Course-Embedded Assessment to Validate Program Outcomes and Course Objectives. Proceedings of the 2004 ASEE Annual Conference \& Exposition, Salt Lake, Utah

14.Davis, K. 2004. Assessment Opportunities in a Capstone Design Course. Proceedings of the 2004 ASEE Annual Conference \& Exposition, Salt Lake, Utah

15. Garry, B. 2011. Examples of Rubrics Used to Assess ABET Student Outcomes in a Capstone Course.

Proceedings of the 2011 ASEE North Midwest Conference, Duluth, MN.

16. Mertler, C.A. Designing Scoring Rubrics for Your Classroom. Practical Assessment, Research \& Evaluation, $7(25)$

17. Moskal, B.M. 2000. Scoring Rubrics: What, When and How? Practical Assessment, Research \& Evaluation, $7(3)$

18. Platts-Mills, O. and Bailey, R. 2009. A Framework for Assessing the Influence of Variations between Individual Capstone Experiences. Proceedings of the 2009 ASEE Annual Conference \& Exposition, Austin, TX

19. Dutson, A. J., R. H. Todd, S. P. Magleby and C. D. Sorensen. 1997. A Review of Literature on Teaching

Engineering Design through Project-Oriented Capstone Courses. Journal of Engineering Education 86(1): 17-28

20. Shuman, L.J., M. Besterfiled-Sacre, and J. McGourty. 2005. The ABET "Professional Skills" - Can They be Taught? Can They be Assessed? Journal of Engineering Education 94(1): 41-55

21. Berg, B.L. 2001. Qualitative Research Methods for the Social Sciences, 6th Ed. Allyn and Bacon, New Jersey. 